Association for Information Systems

AIS Electronic Library (AISeL)

ACIS 2005 Proceedings

Australasian (ACIS)

December 2005

\title{
Reflections on the Cross-cultural Delivery of an Information Systems Degree in China
}

Chris Keen

University of Tasmania

Dean Steer

University of Tasmania

Follow this and additional works at: http://aisel.aisnet.org/acis2005

\section{Recommended Citation}

Keen, Chris and Steer, Dean, "Reflections on the Cross-cultural Delivery of an Information Systems Degree in China" (2005). ACIS 2005 Proceedings. 75.

http://aisel.aisnet.org/acis2005/75

This material is brought to you by the Australasian (ACIS) at AIS Electronic Library (AISeL). It has been accepted for inclusion in ACIS 2005

Proceedings by an authorized administrator of AIS Electronic Library (AISeL). For more information, please contact elibrary@aisnet.org. 


\title{
Reflections on the Cross-cultural Delivery of an Information Systems Degree in China
}

\author{
Prof Chris Keen \\ Dean Steer \\ University of Tasmania \\ School of Information Systems \\ University of Tasmania \\ Hobart, Tasmania \\ Email: Chris.Keen@utas.edu.au \\ Email: Dean.Steer@utas.edu.au
}

\begin{abstract}
The School of Information System at the University of Tasmania has been teaching a Bachelor of Information Systems degree at the Shanghai Fisheries University for the past three years. This article critically reflects on the nature of that teaching, the issues that have arisen and the methodology that was adopted to introduce this programme to a Chinese university. A framework for the analysis of international education has been adopted as a means through which to identify each of the issues that have arisen in the delivery and administration of this programme. The findings reflect on impact of the social and cultural contexts in which such international offshore programmes are delivered.
\end{abstract}

\section{Keywords}

Cross-cultural education, critical reflection, internationalisation, teaching and learning.

\section{INTRODUCTION}

The School of Information Systems has entered into a educational venture in two Chinese cities, Shanghai and Fuzhou, to deliver course units from its Bachelor of Information Systems degree to specific campuses in both of those cities. The success in terms of student enrolments, and the level of achievement of those students, have been overwhelming. In semester 2 of 2005 the number of students enrolled in these Chinese programs represents $60.7 \%$ of the total taught equivalent full-time student units (EFTSUs) enrolled in the School of Information Systems.

The introduction, management and development of this offshore international programme has encountered many challenges similar to those reported elsewhere (Curro 2003, McNaught 2003). Now that the programme has been operating for over three years, it is appropriate to critically reflect on the issues raised by this programme, and identify how such a programme could have been better managed, and to analyse the place that staff involved in the programme have been placed within the wider social and cultural contexts of teaching in a Chinese university.

\section{HISTORY}

In 2002 the University of Tasmania joined a consortium of Australian universities for the purpose of delivering degree programs into Chinese tertiary institutions. That consortium, International Education Network (IEN) initially consisted of five Australian universities - Deakin University, Flinders University, Macquarie University, LaTrobe University and the University of Tasmania. IEN operates through a private company, headquartered in Shanghai, that acts as a broker, contract administrator and student recruiting agency. The approach of the IEN consortium was to progressively develop programs in China, rather than seeking to rush into what was obviously a very open market. Careful consideration was given to the choice of Chinese universities, the choice of programs and close cooperation with the provincial Ministries of Education.

Shanghai Fisheries University (SFU) is located in central Shanghai, has been operating for over ninety years and focuses on a scientific programme around aquaculture. In 2001 SFU did not have an Information Systems programme or have collaborative teaching arrangements with any foreign educational providers. SFU approached IEN for inclusion in the consortium programme late in 2001. In early 2002 a senior delegation from SFU visited Australia, including the University of Tasmania, and indicated their desire to have the Bachelor of Information Systems programme delivered in Shanghai. At about that time SFU acquired a new campus at Nanhui, approximately 40 kilometres east of Shanghai and proposed that the BIS degree be delivered on that campus. During mid and late 2002 several visits were made by Tasmanian staff to SFU to negotiate arrangements for the delivery of the programme, and the programme was officially launched to the first class of 304 students in September 2002. 
A building on the Nanhui campus of SFU was dedicated to this programme, and was named the IEN-SFU Institute. In 2002 an accommodation block was completed and a new library was opened on the campus. A ninth, separate faculty was created within SFU to manage this programme, with a newly appointed Dean, Professor Sun. This faculty has since expanded to include the Bachelor of Information Systems and Bachelor of Commerce, both from the University of Tasmania.

The University of Tasmania also introduced two other programs through the IEN consortium in 2002 - a joint Computing-Information Systems programme at Minjiang University in Fuzhou, and a Bachelor of Computing at ZheZiang University of Technology in Hangzhou. Prior to the introduction of these programs the University of Tasmania had relatively little experience with off-shore international delivery, and had been involved in programs in Malaysia and Singapore through its Faculty of Commerce. Most of the international focus of the University had been on recruiting students to study in Tasmania.

\section{THE BACHELOR OF INFORMATION SYSTEMS PROGRAMME}

The delivery of the Bachelor of Information Systems at SFU consists of a four year programme. Students are recruited during the Chinese summer and commence their academic year in September.

In the first year students study English and a number of Chinese units, including political and cultural studies. In addition, they undertake timetabled sporting activities as part of their university experience throughout their degree. The English course is taught by staff who are employed directly by IEN. Students are required to live in dormitories on campus. For the majority of students this is their first experience of living away from home.

In the latter three years of the programme student study a modified version of the Bachelor of Information Systems. In addition, to the fifteen core units taught by the University of Tasmania's School of Information Systems, students are required to study two units taught by the School of Geography and Environmental Studies from the University of Tasmania, and other units taught by SFU. Their overall load is considerably higher than for students who are studying at the University of Tasmania. The Geography and Environment Studies were included at the request of SFU to provide the students with an awareness of environmental issues relevant to the focus of SFU on aquaculture and the natural environment. All University of Tasmania units are taught in English.

A three year degree at the University of Tasmania consists of twenty four course units, or eight units per year. It was agreed that all University of Tasmania units would be taught by Tasmanian staff when they are first offered at SFU. Thereafter, the number of units taught by Tasmanian staff would be limited to eight, or one third of the degree. The units selected for this continuing delivery by Tasmanian staff are all located in the last two years of the BIS degree.

A Tasmanian staff member is responsible for the unit coordination, teaching and assessment of each University of Tasmania unit taught at SFU. Additional administrative support is offered through SFU and the Assistant Dean of International Education in the Faculty of Commerce at the University of Tasmania.

An intensive, block mode of teaching has been adopted for the delivery of each course unit by Tasmanian staff at SFU:

- All course material for the unit is prepared by Tasmanian staff and sent to SFU prior to the commencement of the semester in which the unit will be delivered;

- For a single unit Tasmanian staff typically visit Shanghai for two sessions of block teaching of five working days each to coordinate the course and deliver the lectures. These block teaching periods normally span a single week, during which the lectures and some of the tutorials for the unit are delivered by the visiting staff. A typical teaching pattern is the delivery of four lectures on each of three days, and a further three lectures on the fourth day of a block teaching period. Staff employed by SFU deliver most of the tutorials in the unit over a longer period of time;

- Marking of the assignments and examination scripts for these units is shared between Tasmanian and Chinese staff, with moderation of the results being performed by the Tasmanian unit coordinator;

- The Tasmanian staff involved in the programme maintain regular contact the staff and students at SFU through email, mainly for the purposes of administration and academic counselling of students.

At the completion of the programme students graduate with two degrees, a Bachelor of Science from SFU and a Bachelor of Information Systems from the University of Tasmania.

This programme is considered to be distinct in the following aspects:

- It is a partnership programme between an Australian and a Chinese university, in which the Bachelor of Information Systems is jointly taught and administered by staff from the University of Tasmania and 
Shanghai Fisheries University, and is accredited through the University of Tasmania. This aspect of the programme was considered innovative by the Shanghai Ministry of Education who have shown a strong interest in its introduction and development;

- Students in the programme are effectively studying a double degree programme that covers the requirements of the Bachelor of Information Systems from the University of Tasmania and Bachelor of Science from Shanghai Fisheries University.

\section{A FRAMEWORK FOR INTERNATIONALISATION}

Curro \& McTaggart (2003) have developed a theoretical framework within which to characterise the internationalisation of the university curriculum from the development of a technical observance, through practical deliberation to critically reflective practice. They characterise technical observance as having a focus on operational issues, such as level of recruiting of international students, hiring staff with international teaching experience, modifying the curriculum for international delivery, and remedying the problems associated with a poor knowledge of English. Practical deliberation is characterised by Curro \& McTaggart as a re-creation of the organisational, educational and social practices that leads to new forms of intercultural relationships, including redefining curriculum, building organisational structures that support international and intercultural partnerships, staff development and "research into, and evaluation of, curriculum, teaching and learning, and learning support" (p2).

Hatton \& Smith (1995) have defined critical reflection as

Involving moral and ethical criteria, making judgements about whether professional activity is equitable, just and respectful of persons or not. In addition, critical reflection locates any analysis of personal action within wider socio-historical and politico-cultural contexts (p.35)

Critical reflection requires theoretical and practical approaches to cultural awareness, and both organisational and personal perspectives. In terms of international education critical reflection requires a sensitivity to intercultural issues that transcends racism and the sense of the "otherness" implied by the use of titles, such as "international" or "overseas" students, and but rather encourages an acceptance of the partnership and inclusiveness of teaching and learning processes on a scale that spans international and cultural boundaries (Curro \& McTaggart 2003).

The traditional development of Australian tertiary education has focussed on national goals and the adoption of international students within those goals of growth and pursuit of excellence. A change of emphasis in this approach is demonstrated by such phrases as the following in induction material for University of Tasmania staff who are involved in off-shore teaching:

Offshore education provides, among other things, an opportunity for improved cross-cultural understandings and enhanced commitment to global issues. It provides an avenue for discourses other than the dominant Western literacy to be honoured. Offshore education clearly serves a function above and beyond the financial imperative (Flexible Education Unit 2004).

Curro \& McTaggart (2003) summarise the entry to international education as involving changes in three areas:

- The acquisition of new skills, beyond those required to teach international students in Australia;

- The development of new understandings, leading to new curricula and teaching practices; and

- The adoption of new values that will influence their curriculum design, and approaches to social, organisational and personal practices.

An example of the manner in which international educators need to adjust their understandings and values has been provided by Wong \& Wen (2001) in their comparative study of the understanding of conceptions of learning held by students at Hong Kong University and Nanjing University. They used an analysis of the conceptualisation of learning based on the following five factors:

1. Memorising, reproducing and understanding

2. Applying

3. Learning processes

4. Seeing things differently and improving oneself

5. Memorisation and understanding

Students from both universities consistently saw factors (2-4) as being more significant than (1) or (5). This appreciation was more pronounced in the students from Nanjing University than for students at Hong Kong University. These findings contradict the stereotypical view that students from a Confucian-heritage culture have 
the characteristic that "They rote learn and lack critical thinking skills" (Biggs 2003, p.125). As Wong and Wen (2001) summarise: "Confucian-heritage culture students out-perform western students, at least in science and mathematics, and have deeper and more meaning-oriented, approaches to learning".

Curro \& McTaggart (2003) argue that pedagogical innovation requires changes in aspects of practice:

- Communication - language, symbols and other representations of teaching;

- Organisation - relationships between teachers, learners and administrators;

- Production - curriculum development, course delivery, management, teacher education and evaluation of teaching and learning.

They propose that educational practices can be characterised at four levels, Curriculum, Administration, Teacher Development and Educational Research \& Evaluation, as shown in Table 1.

\begin{tabular}{|c|c|c|c|}
\hline Educational Practices & Communication & Production & Social Organisation \\
\hline Curriculum & Curriculum content & Pedagogy & $\begin{array}{c}\text { Classroom authority and } \\
\text { control }\end{array}$ \\
\hline Technical Observance & $\begin{array}{l}\text { Acknowledgement of } \\
\text { international authors in } \\
\text { the field }\end{array}$ & $\begin{array}{l}\text { Correct pronunciation of } \\
\text { student names }\end{array}$ & Polite Western manners \\
\hline Practical Deliberation & $\begin{array}{l}\text { Teaching examples from } \\
\text { other cultures }\end{array}$ & $\begin{array}{l}\text { Deliberate questioning of } \\
\text { students from different } \\
\text { cultures in sample } \\
\text { perspectives }\end{array}$ & $\begin{array}{l}\text { Consultation with students } \\
\text { about preferred classroom } \\
\text { relationships }\end{array}$ \\
\hline Critical Reflection & $\begin{array}{l}\text { Competing cultural } \\
\text { explanations and } \\
\text { perspectives presented for } \\
\text { students to compare }\end{array}$ & $\begin{array}{l}\text { Curriculum changes in } \\
\text { dialogue with students to } \\
\text { reflect cultural preferences } \\
\text { and to nurture collaborative } \\
\text { learning practices for deep } \\
\text { learning and cross-cultural } \\
\text { critique }\end{array}$ & $\begin{array}{l}\text { Use of foreign language } \\
\text { forms of address, idioms and } \\
\text { patterns of respect and } \\
\text { deference }\end{array}$ \\
\hline Administration & Educational policy & Administrative practices & $\begin{array}{c}\begin{array}{c}\text { Relations of authority and } \\
\text { evaluation }\end{array} \\
\end{array}$ \\
\hline Technical Observance & $\begin{array}{l}\text { Policy emphasises } \\
\text { equality of opportunity }\end{array}$ & $\begin{array}{l}\text { Service staff trained to deal } \\
\text { with students from different } \\
\text { cultures, especially students } \\
\text { from Non-English speaking } \\
\text { backgrounds }\end{array}$ & $\begin{array}{l}\text { Staff invited to undertake } \\
\text { cultural sensitivity training }\end{array}$ \\
\hline Practical Deliberation & $\begin{array}{l}\text { Policy emphasises staff } \\
\text { development for cultural } \\
\text { sensitivity and } \\
\text { inclusiveness }\end{array}$ & $\begin{array}{l}\text { Staff of different cultures } \\
\text { are appointed }\end{array}$ & $\begin{array}{l}\text { Cultural sensitivity training } \\
\text { required of all staff as part of } \\
\text { a performance management } \\
\text { programme }\end{array}$ \\
\hline Critical Reflection & $\begin{array}{l}\text { Policy emphasises } \\
\text { representation of cultural } \\
\text { perspectives in all } \\
\text { university practices }\end{array}$ & $\begin{array}{l}\text { Active recruitment and } \\
\text { support of academic and } \\
\text { general staff to move the } \\
\text { ethnicity profile of staff } \\
\text { towards that of students }\end{array}$ & $\begin{array}{l}\text { Policies and practices } \\
\text { systematically and regularly } \\
\text { evaluated by stakeholders } \\
\text { including community groups }\end{array}$ \\
\hline Teacher Development & Curriculum content & Pedagogy & $\begin{array}{c}\text { Classroom authority and } \\
\text { control }\end{array}$ \\
\hline $\begin{array}{c}\text { Educational Research } \\
\text { \& Evaluation } \\
\end{array}$ & Educational theory & $\begin{array}{c}\text { Research \& evaluation } \\
\text { practices }\end{array}$ & $\begin{array}{c}\begin{array}{c}\text { Politics of research } \& \\
\text { evaluation }\end{array} \\
\end{array}$ \\
\hline
\end{tabular}

Table 1. Examples of Internationalisation: University Curriculum and Context, from Curro \& McTaggart (2003).

Table 1 shows how the four levels of Curriculum, Administration, Teacher Development and Educational Research \& Evaluation can be further broken down into responses characterised by Technical Observance, 
Practical Deliberation and Critical Reflection. The breakdown of Educational Practices associated with Teacher Development, and Educational Research \& Evaluation have been omitted from this table for brevity. Clearly the examples cited in this table are more relevant to the context of international students studying in a foreign country than to a university delivering its degrees into a foreign country. However, this framework provides a useful model against which to reflect on the planning, policies and practices of an off-shore delivery programme.

\section{THE UNIVERSITY OF TASMANIA EXPERIENCE}

Interviews were conducted with staff from the School of Information Systems who had been involved in the unit coordination and delivery of course units at universities in Fuzhou and Shanghai along the intensive, block mode of teaching described above.

Negotiations for the delivery of the University of Tasmania degree into Shanghai Fisheries University (SFU) commenced in entry 2002 and continued through the middle of that year, with several visits by senior staff from both universities. 304 students were initially recruited for the four year programme at Shanghai Fisheries University, with the first intake being in September 2002. The University of Tasmania BIS units were introduced from September 2003 onwards, so that at the time of writing the School of Information Systems is in its fifth semester of delivery of units at the Shanghai campus. The School of Information Systems was also involved in a joint programme with the School of Computing and Minjiang University in Fuzhou. The delivery of Information Systems units commenced there in the second half of 2003.

Initially the University of Tasmania staff regarded the delivery of the BIS degree at Shanghai Fisheries University as similar to the practice of teaching a programme at another campus. They were very familiar with this model as the Information Systems programme had already been taught on three campuses: Hobart, Launceston and Burnie, with some minor delivery in Singapore. There was a strong emphasis by all parties involved in the early negotiations on the need for effective quality control of the content and delivery of the degree in Shanghai. Over the three years since its introduction, an increasing awareness has arisen of the inter-cultural challenges of the programme, but many of the practices associated with the delivery of the programme have not changed.

\begin{tabular}{|c|c|c|c|}
\hline Educational Practices & Communication & Production & Social Organisation \\
\hline Curriculum & Curriculum content & Pedagogy & $\begin{array}{c}\text { Classroom authority and } \\
\text { control }\end{array}$ \\
\hline Technical Observance & $\begin{array}{l}\text { Recognition by Chinese } \\
\text { students of the western } \\
\text { approach to assignments all } \\
\text { being counted towards } \\
\text { assessment }\end{array}$ & $\begin{array}{l}\text { Provision of training in } \\
\text { Chinese language and } \\
\text { pronunciation to visiting } \\
\text { Tasmanian staff }\end{array}$ & $\begin{array}{l}\text { Provision of training in } \\
\text { Chinese protocol and } \\
\text { etiquette to visiting } \\
\text { Tasmanian staff }\end{array}$ \\
\hline Practical Deliberation & $\begin{array}{l}\text { Communicating business and } \\
\text { ICT examples that are } \\
\text { meaningful to Chinese } \\
\text { students }\end{array}$ & $\begin{array}{l}\text { Developing an awareness } \\
\text { of the Chinese education } \\
\text { system by visiting } \\
\text { Tasmanian staff }\end{array}$ & $\begin{array}{l}\text { Developing appropriate } \\
\text { modes of interaction with } \\
\text { Chinese students in } \\
\text { lectures and tutorials }\end{array}$ \\
\hline Critical Reflection & $\begin{array}{l}\text { Acquiring an understanding } \\
\text { of the learning culture } \\
\text { associated with the Chinese } \\
\text { education system and } \\
\text { integration of the proposed } \\
\text { curriculum with that } \\
\text { education system }\end{array}$ & $\begin{array}{l}\text { Planning for the adaptation } \\
\text { of the curriculum in } \\
\text { dialogue with Chinese } \\
\text { students and SFU staff to } \\
\text { reflect cultural preferences } \\
\text { and to nurture } \\
\text { collaborative learning } \\
\text { practices for deep learning } \\
\text { and cross-cultural critique }\end{array}$ & $\begin{array}{l}\text { Developing an understand } \\
\text { of the roles that language, } \\
\text { social interactions and } \\
\text { relationships between } \\
\text { student and lecturer play in } \\
\text { the educational process in } \\
\text { China }\end{array}$ \\
\hline Administration & Educational policy & Administrative practices & $\begin{array}{l}\text { Relations of authority } \\
\text { and evaluation }\end{array}$ \\
\hline Technical Observance & $\begin{array}{l}\text { Ensuring that both Chinese } \\
\text { and Australian students } \\
\text { receive the same curriculum }\end{array}$ & $\begin{array}{l}\text { Employing an intensive, } \\
\text { block mode of teaching } \\
\text { that limited the ability of }\end{array}$ & $\begin{array}{l}\text { Provision of induction } \\
\text { programmes to Tasmanian } \\
\text { staff prior to visiting China }\end{array}$ \\
\hline
\end{tabular}




\begin{tabular}{|c|c|c|c|}
\hline & and forms of assessment & $\begin{array}{l}\text { the Tasmanian staff to } \\
\text { observe and adapt their } \\
\text { teaching methods during } \\
\text { their visits } \\
\text { Provision of adequate } \\
\text { access to the e-learning } \\
\text { management system, } \\
\text { WebCT for Chinese } \\
\text { students }\end{array}$ & \\
\hline Practical Deliberation & $\begin{array}{l}\text { Professional development of } \\
\text { Chinese staff who have } \\
\text { visited Tasmania for } \\
\text { semester-long periods to } \\
\text { enhance their understanding } \\
\text { of a western university system }\end{array}$ & $\begin{array}{l}\text { Appointment of a staff } \\
\text { member who was born in } \\
\text { Shanghai and is now living } \\
\text { in Tasmania } \\
\text { Recruitment of additional } \\
\text { staff who are culturally } \\
\text { aware and sensitive to } \\
\text { teaching in China }\end{array}$ & $\begin{array}{l}\text { Dealing with disputes with } \\
\text { participating staff over } \\
\text { status of China service and } \\
\text { payment of inconvenience } \\
\text { allowance } \\
\text { Formation of a true, equal } \\
\text { partnership between the } \\
\text { two universities }\end{array}$ \\
\hline Critical Reflection & $\begin{array}{l}\text { Development by the } \\
\text { University of Tasmania } \\
\text { (2004) of induction material } \\
\text { that emphasised the } \\
\text { development of culturally } \\
\text { aware and sensitive teaching } \\
\text { programmes }\end{array}$ & $\begin{array}{l}\text { Provision of appropriate } \\
\text { debriefing sessions for } \\
\text { staff on return from China } \\
\text { visits }\end{array}$ & $\begin{array}{l}\text { Formation of an education } \\
\text { management committee to } \\
\text { monitor and review the } \\
\text { programme delivery on a } \\
\text { regular basis }\end{array}$ \\
\hline
\end{tabular}

Table 2. A summary of the issues raised through the experience of University of Tasmania staff teaching in China

Table 2 illustrates a range of issues that staff from the School of Information Systems who have been involved in teaching in China have experienced. These issues have been classified according to the model developed by Curro \& McTaggart (2003).

At the level of the individual University of Tasmania staff member there has been a lack of provision of appropriate induction programmes prior to these staff going to China. The intensive, block mode of teaching limits the time that staff have in China to adapt their teaching practices and material. Uncertainty about social practices in Chinese classrooms and lack of knowledge of the Chinese education system has also inhibited these staff in their ability to interact with Chinese students and effectively establish a dialogue of inquiry in the classroom.

At the level of the School of Information Systems the original plan was to develop a small group of specialised staff who were trained in teaching and learning in China. However, in practice the China teaching load has been spread across many staff members of the School. One staff member was appointed who was born in Shanghai, but the extent to which that staff member has been able to influence the curriculum redesign and delivery of the education programme in China has been limited.

Initially it was planned to have one postgraduate or staff member resident in Shanghai for a semester period to provide ongoing tutorial and academic counselling support for Chinese students. However, this practice was discontinued after one semester, much to the disappointment of the Chinese students.

Disputes have arisen with University of Tasmania staff over the status of teaching in China, whether it is to be regarded as on or off load, and how staff are to be compensated financially for the inconvenience and real additional costs associated with being in China.

At the University level the programme to deliver the BIS into China has not exploited the knowledge and expertise that exists in the University, such as consulting with staff from the School of Asian Studies. The University did not produce comprehensive induction material (Flexible Education Unit 2004) that covered the pedagogical and cultural issues associated with teaching international students until 2004, two years after the introduction of the off-shore programme. Access to the WebCT e-learning management system employed by the University of Tasmania has been less than satisfactory in China, due to slow network access rates over the Internet.

The teaching of Information Systems at SFU and in Fuzhou has presented a number of specific problems: 
- The Chinese students have a limited awareness of relevant business systems and processes, such as banking systems and banking procedures beyond their experience with the use of automatic teller machines;

- Many of the students enrolled in the programme appear to be unsure as to whether the degree has an emphasis on technical ICT or upon business systems, and do not appreciate the joint approach of the course;

- The English language programme has prepared the Chinese students with a knowledge of general English, but the programme has only provided limited introduction to ICT and business jargon and phrases. In addition, the students have had limited exposure to ICT and western business language jargon and phrases through the Chinese media;

- The development of skills in the analysis of case studies and in abstract problem analysis, especially when working in small groups, and of systems thinking, have not been explicitly covered and practised with the Chinese students. While these students tend to focus on convergent styles of problem solving (Lopez-Real \& Mok 2001) they have the intellectual ability, but not the cultural awareness of dealing with divergent problem resolution. The same claim can also be made of many Australian students, of course;

- Plagiarism has been a problem, although not a major issue. It has been apparent in computer programming units, and in more advanced units where students often lack the skills in English to express themselves, and so resort to various forms of paraphrasing copied material. While students are generally aware of the concepts associated with plagiarism, they have lacked exposure to actual illustrative examples, and often do not appear to be aware of the severity of plagiarism;

- Chinese students are not accustomed to buying relatively expensive textbooks, and so provision of adequate numbers of both required and reference textbook material to these classes has been a problem.

\section{FINDINGS}

Use of Table 1 for the purpose of classification has enabled the categorisation of relevant issues from this programme into:

- Issues relevant to the individual staff member and particular course units delivered to international students;

- Issues relevant to the organisational unit, such as the School/Department or teaching team who are responsible for the management of delivery of courses to international students; and

- Issues relevant to the institution that has contracted to deliver courses to international bodies.

Obviously these three levels are not independent as decisions made at a higher level can constrain and otherwise impact policies and practice at lower levels.

As highlighted by Biggs (2003), the following stereotypical views associated with the teaching and learning of international students do not apply:

- "They rote learn and lack critical thinking skills"

- "They are passive; they won't talk in class"

- "They don't know what plagiarism means"

Rather, the key issues identified by Tasmanian staff that inhibit the effectiveness of their teaching and learning related to the contextual issues of culture, Chinese society and the Chinese education system. The staff were unaware of the nature of the teaching and learning experience of the Chinese students through their schooling and early university years. As a consequence Tasmanian staff felt uncomfortable in not knowing the accepted manner of interaction with Chinese students in the class room. This uncomfortable feeling led to inhibitions on the part of the Tasmanian lecturers in the classroom, rather than the stereotypical view that the lack of communication could be ascribed to passive students.

A further example of the lack of awareness of contextual issues by a Tasmanian staff member occurred with the reaction by Chinese students to the amount of emphasis placed upon the completion of assignments. One Tasmanian staff member suspected that this was due to such assignments not be part of the assessment regime in Chinese courses. The staff member could not adequately understand or explain the differential motivation of Chinese students towards assignments and examinations. Similar results have been reported by Woodrow \& 
Chapman (2002) with regard to the teaching and learning of English by Chinese students, and been partly ascribed to the collectivist culture of China.

Most of the dialogue between the Tasmanian and Chinese institutions has concerned administrative and contractual matters. There has been very little dialogue at the level of curriculum redesign and implementation, and pedagogical issues, except between individual lecturers. This situation has applied both during visits by Tasmanian staff to China and when Chinese staff have undertaken extended visits to Tasmania. In fact, in one instance a Tasmanian staff member was instructed not to discuss pedagogical issues with Chinese staff while visiting and teaching in China. An over-riding concern with the restricted use of appropriate protocol channels has limited communication between all parties involved in the programme.

The Flexible Education Unit of the University of Tasmania produced a draft document entitled Teaching and Learning: Induction Materials for UTas Staff Working with Offshore Students in 2004. While this document is very comprehensive in its coverage of issues and proposals for the planning and delivery of courses at offshore institutions, it was published two years after the delivery of the BIS programme had commenced at SFU.

\section{LESSONS LEARNED AND ADVICE}

From the experience gained in the delivery of this programme at SFU the lessons that have been learnt and consequent advice offered to other institutions involved in similar ventures is summarised in Table 3.

\begin{tabular}{|c|c|}
\hline ILLUSTRATIVE OBSERVATIONS & ADVICE \\
\hline $\begin{array}{l}\text { The selection of teaching staff to be involved in the } \\
\text { programme on the basis of subject knowledge and } \\
\text { the provision of relatively little preparation for cross- } \\
\text { cultural teaching does not lead to outcomes } \\
\text { approaching best practice. }\end{array}$ & $\begin{array}{l}\text { Teaching staff need to be selected on the basis of } \\
\text { their aptitude to the challenges of cross-cultural } \\
\text { teaching in a foreign country. They need to be } \\
\text { trained for this purpose, and need to have developed } \\
\text { skills in conflict resolution and negotiation. In } \\
\text { particular, senior staff often have the teaching } \\
\text { experience, are highly respected and have the } \\
\text { entrepreneurial skills to generate the diverse returns } \\
\text { from international programmes (Debowski, 2003) }\end{array}$ \\
\hline $\begin{array}{l}\text { Two years into the programme, at a Tasmanian } \\
\text { dinner for visiting senior Chinese staff from SFU, it } \\
\text { became apparent that neither party had a good } \\
\text { knowledge of the basic roles, responsibilities and } \\
\text { organisational structure of the others' university. }\end{array}$ & $\begin{array}{l}\text { Preparation for involvement in the programme needs } \\
\text { to cover issues associated with social, educational } \\
\text { and business cultures, and also the institutional } \\
\text { cultures of the partner universities, at all levels of } \\
\text { staff involved in the programme. }\end{array}$ \\
\hline $\begin{array}{l}\text { The existing instrument used for unit-based surveys } \\
\text { for the student evaluation of teaching and learning at } \\
\text { the University of Tasmania is considered to not be } \\
\text { suitable for use in international delivery at offshore } \\
\text { institutions, and has been withheld in semester } 2 \text { of } \\
2005 \text {. }\end{array}$ & $\begin{array}{l}\text { The survey instrument for student evaluation of } \\
\text { teaching and learning needs to be reworded and } \\
\text { better explained, so that its purpose and content is } \\
\text { comprehensible to international students. The } \\
\text { expectations of international students, their } \\
\text { perception of the outcomes of unit completion, and } \\
\text { their norms in evaluating teaching and learning need } \\
\text { to be better understood and communicated when } \\
\text { using such survey instruments. }\end{array}$ \\
\hline $\begin{array}{l}\text { Staff involved in the programme have not been } \\
\text { encouraged to understand the other institutions' } \\
\text { cultural landscapes. }\end{array}$ & $\begin{array}{l}\text { The true partnership aspects of the relationship } \\
\text { between the two institutions need to emphasized, and } \\
\text { staff equipped and encouraged to explore the others' } \\
\text { culture and the inter-cultural interactions. }\end{array}$ \\
\hline $\begin{array}{l}\text { Much of the policy associated with the programme } \\
\text { has been continuously developed on an ad hoc basis, } \\
\text { with mainly verbal communication to the staff } \\
\text { involved. }\end{array}$ & $\begin{array}{l}\text { Expectations associated with the programme need to } \\
\text { be documented, disseminated and adopted using the } \\
\text { uniform format of a contract and evolving service } \\
\text { level agreement, so that it is clear to all staff } \\
\text { involved in the programme. Adequate provision } \\
\text { needs to be made for dispute resolution, both }\end{array}$ \\
\hline
\end{tabular}




\begin{tabular}{|l|l|} 
& $\begin{array}{l}\text { between institutions and within institutions, with } \\
\text { respect to the operation of the programme. }\end{array}$ \\
\hline $\begin{array}{l}\text { Individual teaching staff involved in the delivery of } \\
\text { international programmes are often loaded with } \\
\text { 'unseen' duties of remote course coordination, } \\
\text { marking, moderation of assessment, individual } \\
\text { student counselling and meeting administrative } \\
\text { deadlines. }\end{array}$ & $\begin{array}{l}\text { A team approach to the delivery of international } \\
\text { programmes should be adopted with distinct roles of } \\
\text { cooptinators, local and remote student counsellors, } \\
\text { quality assurers and e-learning content managers } \\
\text { (Debowski, 2003). }\end{array}$ \\
\hline $\begin{array}{l}\text { Despite many superficial differences between the } \\
\text { partner institutions, there are also many similarities } \\
\text { in pedagogical objectives, and in the bureaucratic } \\
\text { processes of each institution. }\end{array}$ & $\begin{array}{l}\text { Greater emphasis needs to be placed on the } \\
\text { successful implementation of joint partnerships } \\
\text { between cross-cultural programmes, } \\
\text { encouragement to understand the } \\
\text { responsibilities, organisational structures, and social } \\
\text { and political contexts of each institution. }\end{array}$ \\
\hline
\end{tabular}

Table 3. A summary of the some lessons learned and relevant advice offered from the experience of University of Tasmania staff teaching in China

\section{CRITICAL REFLECTIONS}

When the programme to deliver the BIS degree at FSU in Shanghai was first discussed, the senior SFU staff emphasised that they wanted the same curriculum content, same assessment and also same mode of teaching in China as in Tasmania. In particular, they wanted learning through problem oriented discussion in small groups, as they had seen in final year classes in Tasmania. They re-equipped several classrooms on the SFU campus to permit this style of teaching. Unfortunately, little real debate of the feasibility and even desirability of these requirements have taken place, and the practical extent to which they have been achieved is questionable. A lack of understanding and real engagement with the Chinese education system has limited the extent to which the same modes of teaching and learning have been achievable.

The delivery of the BIS into China is viewed by some at the University of Tasmania as a service delivery function. The wider implications of the programme for increased cultural awareness, enrichment and diversification of research have been ignored in the implementation of the programme. The limited funds available in return for delivery of the programme has also restricted the extent to which the staff involved have wanted, or been able, to expand the scope of the programme.

Teaching staff can focus on their perceived limitations of the Confucian mode of teaching and learning in which the students appear to consider "there is only one right answer", and may defer to others with higher status in the classes to provide the more correct answer. Alternatively such teaching staff can adopt a constructive approach to engagement with such a educational culture, "and to plan for the teaching of reflective and synergistic learning" (Debowski, 2003). It was very apparent in early discussions with senior SFU staff that they wanted Tasmanian teaching staff to foster independent inquiry, to develop discursive skills, and to encourage critical thinking by Chinese students.

Ryan \& Hellmundt (2003) have also reported that lack of time, budget restrictions and heavy workloads have impeded the extent to which staff are capable of understanding, assimilating and enriching their teaching practices in a foreign environment. They also regarded such pressure as counter to what many staff regard as the purpose of university education - "developing independent, critical think and intercultural skills in students".

Undoubtedly the successes of the programme has been due to the work that staff from all parties in the programme have been dedicated to the effective delivery of the programme in China. The rapport that has developed directly between Tasmanian staff and Chinese staff and students has clearly been a major factor in the ongoing effective delivery of the programme.

\section{REFERENCES}

Biggs, J. (2003) Teaching for Quality Learning at University, $2^{\text {nd }}$ Ed, The Society for Research into Higher Education \& Open University Press, Buckingham.

Curro (2003) “Teaching the Chinese Learner”, Issues in Teaching and Learning @ JCU, 1 (2), 19 March 2003. 
Curro, G. \& McTaggart, R. (2003) “Supporting the Pedagogy of Internationalisation", Proceedings of the 17 IDP Australian International Education Conference, 21-24 Oct 2003, Melbourne, Australia.

Debowski, S. (2003) "Lost in Internationalised Space: The Challenge of Sustaining Academics Teaching Offshore", Proceedings of the 17 $7^{\text {th }}$ IDP Australian International Education Conference, 21-24 Oct 2003, Melbourne, Australia.

Hatton, N. \& Smith, D. (1995) "Reflection in teacher education: Towards definition and implementation", Teaching and Teacher Education, 11(1), 33-49.

Lopez-Real, F.J. \& Mok, I.A.C. (2001) “Is there a Chinese Pedagogy of Mathematics Teaching?” CERCular, Newsletter of the Comparative Education Research Centre, Nos. 1 \& 2, University of Hong Kong.

Flexible Education Unit (2004) Teaching and Learning: Induction Material for UTas Staff Working with Offshore Students, University of Tasmania.

McNaught, C. (2003) "Supporting the Global eTeacher", Proceedings of the eLearn International 2003 World Conference, 9-12 February 2003, Edinburgh.

Ryan, J. \& Hellmundt, S. (2003) "Excellence Through Diversity: Internationalisation of Curriculum and Pedagogy", Proceedings of the 17 $7^{\text {th }}$ IDP Australian International Education Conference, 21-24 Oct 2003, Melbourne, Australia.

Wong, K-C. \& Wen Q. (2001) "The Impact of University Education on Conceptions of Learning: A Chinese Study", International English Journal, 2 (5), 138-147.

Woodrow, L. \& Chapman, E. (2003) “Assessing the Motivational Goal Orientations of International English for Academic Purposes (EAP) Students”, Current Research in Social Psychology, 7 (15).

\section{COPYRIGHT}

C Keen \& D Steer, (C) 2005. The authors assign to ACIS and educational and non-profit institutions a nonexclusive licence to use this document for personal use and in courses of instruction provided that the article is used in full and this copyright statement is reproduced. The authors also grant a non-exclusive licence to ACIS to publish this document in full in the Conference Papers and Proceedings. Those documents may be published on the World Wide Web, CD-ROM, in printed form, and on mirror sites on the World Wide Web. Any other usage is prohibited without the express permission of the authors. 